\title{
PERENCANAAN PRODUK
}

\author{
Hanan Fakhira Sa'diyyah \\ Naura Aulia Hafidzah \\ Muhammad Zaidan Mubarak \\ Mumuh Mulyana \\ Sofie Kurnia Asih
}

Selamat berjumpa lagi. Saat ini Anda memasuki materi inisiasi IV yang akan membahas materi Perencanaan Produk. Untuk itu Anda harap mempelajari modul 4 dari BMP Perencanaan Pemasaran (EKMA 4569). Jangan lupa untuk mengerjakan tes formatif modul 4 untuk mengevaluasi kemampuan pemahaman Anda tentang materi tersebut.
Kompetensi Umum
: Mahasiswa diharapkan mampu memahami dan menjelaskan konsep dasar dan perancangan perencanaan pemasaran serta aplikasinya dalam bauran pemasaran
Kompetensi Khusus
: Mampu menjelaskan dan merumuskan Perencanaan Produk
Menjelaskan Strategi Produk
Menjelaskan Perencanaan Pengembangan Produk Baru
Menjelaskan Perencanaan Pemasaran Produk Baru
Menjelaskan Analisis Daur Hidup Produk
Menjelaskan Perencanaan Strategis Dalam Setiap Tahapan
Daur Hidup Produk

\section{Sumber Belajar}

1. Utama

Modul 4 EKMA4569

Perencanaan Pemasaran. Daniel Tumpal. Universitas Terbuka. 2016

2. Tambahan:

- Marketing Management : A Strategic Decision-Making Approach. John W. Mullins and Orville C. Walker, Jr. $7^{\text {th }}$ edition. McGraw-Hill International Edition. 2010

- New Products Management. Merle Crawford and Anthony Di Benedetto. 10 ${ }^{\text {th }}$ Edition. McGraw-Hill International Edition. 2011

\section{Rangkuman Materi Kuliah}

Produk sangat penting untuk mencapai sasaran pemasaran. Kesenjangan yang terjadi antara tren/ramalan penjualan dengan tujuan perusahaan dapat dijembatani dengan : 
1. Peningkatan produktivitas.

2. Penetrasi pasar dilakukan dengan meningkatkan fungsi produk, meningkatkan pangsa pasar, dan lain-lain.

3. Pengembangan produk baru.

4. Pengembangan pasar baru (contohnya: kelompok pengguna baru, memasuki segmen pasar baru, ekspansi geografis).

5. Kombinasi produk dan pasar baru.

6. Penerapan strategi baru (contohnya: akuisisi, lisensi waralaba, joint venture).

Strategi produk dibedakan menjadi strategi reaktif dan proaktif. Strategi reaktif berkaitan dengan tekanan dari luar yang memaksa organisasi melakukan aksi. Strategi proaktif secara eksplisit mengalokasikan sumber daya untuk mengidentifikasi dan menangkap kesempatan serta mengantisipasi kejadian yang tidak menguntungkan.

Pengembangan produk dilakukan melalui tahapan berikut :

1. audit pasar;

2. analisis SWOT;

3. penetapan tujuan;

4. kriteria persetujuan;

5. pembangkitan ide;

6. pemilahan ide;

7. pengujian konsep;

8. analisis bisnis;

9. pengembangan produk;

10. pengujian;

11. komersialisasi.

Proses desain produk merupakan bagian dari strategi proaktif di mana langkah-langkahnya adalah:

1. Mengidentifikasi kesempatan.

2. Memproses desain produk untuk memanfaatkan kesempatan tersebut.

3. Melakukan pengujian produk dan program pemasarannya.

4. Meluncurkan produk dan penelusuran jalannya produk baru.

5. Mengelola daur hidup produk.

Dalam melakukan perencanaan pemasaran produk baru, perlu diperhatikan pengujian pasar produk sebelum meluncurkan produk dalam skala penuh. Pertama-tama menguji unsur periklanan dan fisik produk. Kemudian pengujian melalui pretes pasar. Kekurangan yang muncul diumpan balikkan ke tahapan desain. Langkah terakhir, produk diatur untuk diuji dalam tes 
pasar. Jika produk sukses di tes pasar, ia bisa diluncurkan secara penuh di pasar. Jika tidak, ia harus dikembalikan ke tahapan desain.

Semua produk mempunyai daur hidup. Konsep daur hidup produk berguna untuk memprediksikan pola penjualan di masa yang akan datang. Anda dapat memilih strategi apa yang harus diterapkan sesuai dengan posisi produk dalam daur hidup. Karenanya, terlebih dahulu Anda harus menetapkan posisi produk Anda dalam daur hidup. Memposisikan produk dilakukan dengan memperhitungkan perkiraan penjualan, laba, marjin, pangsa pasar, dan harga produk pada setiap tahapan dalam daur hidup.

Strategi yang dapat diterapkan dalam tahapan perkenalan adalah strategi harga skimming dan strategi harga penetrasi. Pada tahapan pertumbuhan strategi yang tepat adalah membangun kesadaran merek, pengembangan produk, mencari pasar baru, pengurangan biaya, promosi, dan penurunan harga. Pada tahapan kedewasaan, strategi yang dapat diterapkan adalah strategi mempertahankan, strategi defensif, dan strategi inovasi produk. Sedangkan pada tahapan penurunan, pilihan strategi yang digunakan adalah penarikan produk dan fokus pada pemakai setia

\section{Referensi :}

[1] Tumpal, Daniel, 2016. Perencanaan Pemasaran. Universitas Terbuka.

[2] McDonald, Malcolm and Wilson, Hugh. 2011. Marketing Plans: How To Prepare Them, How To Use Them. $7^{\text {th }}$ edition. Wiley.

[3] Mullins, John W. and Walker, Jr. Orville C., 2010. Marketing Management : A Strategic Decision-Making Approach. $7^{\text {th }}$ edition. McGraw-Hill International Edition.

[4] O’Guinn, Thomas C.; Allen, Chris T. and Semenik, Richard J., 2009. Advertising \& Integrated Brand Promotion. $5^{\text {th }}$ Edition. South-Western Cengage Learning.

[5] Crawford, Merle and Benedetto, Anthony Di 2011. New Products Management. 10 Edition. McGraw-Hill International Edition. 2011.

[6] Mulyana, Mumuh. 2019. "STRATEGI PROMOSI DAN KOMUNIKASI.” INA-Rxiv. June 12. doi:10.31227/osf.io/v7dfr.

[7] Mulyana, Mumuh. 2019. "MENGANALISIS PERILAKU KONSUMEN.” INA-Rxiv. June 12. doi:10.31227/osf.io/2wj34.

[8] Mulyana, M., 2012. Consumer Behaviour: Sukses Dengan Memahami Konsumen.

[9] Mulyana, M. and Sulistiono, S., 2012. Kewirausahaan: The Long Life Way of Business.

[10] Pauziah, P. and Mulyana, M., 2018. Formulation of The Green Marketing Development Strategy for the Body Shop Botani Square Bogor. In THE INTERNATIONAL CONFERENCE ON ACCOUNTING AND MANAGEMENT SCIENCE (p. 171).

[11] Hidayat, L., Mulyana, M. and Effendy, M., 2018. Membangun Kepuasan Mahasiswa Pengguna Laboratorium Komputer. JAS-PT Jurnal Analisis Sistem Pendidikan Tinggi, 1(2), pp.93-101.

[12] Mulyana, M., PERSEPSI DAN PERILAKU KONSUMEN TERHADAP ONLINE SHOPPING. 